\title{
The history of archaeological research at the site of the former Kulmhof extermination camp
}

Andrzej Grzegorczyk Muzeum Tradycji Niepodległościowych w Łodzi/oddział Stacja Radegast (Museum of Independence Traditions in Lodz, Radegast Station Division)

a.grzegorczyk@muzeumtradycji.pl

\begin{abstract}
The Kulmhof extermination camp in Chełmno nad Nerem was the first camp set up by the Nazis to exterminate Jews during the Second World War. The history of Kulmhof has long been an area of interest for academics, but despite thorough research it remains one of the least-known places of its kind among the public. Studies of the role of archaeology in acquiring knowledge about the functioning of the camp have been particularly compelling. The excavations carried out intermittently over a thirty-year period (1986-2016), which constitute the subject of this article, have played a key role in the rise in public interest in the history of the camp.
\end{abstract}

Key words: Holocaust, Kulmhof, Chełmno nad Nerem, extermination camp, conflict archaeology, memorial site

\section{Introduction}

The history of the Kulmhof extermination camp in Chełmno nad Nerem has frequently been the subject of scientific research over the years. ${ }^{1}$ These studies have revealed much about the history of the camp, which was the first centre for the instantaneous extermination of Jews. Despite thorough research, it remains one of the least-known places of its kind among the public. This is primarily a result of the scarcity of sources, ${ }^{2}$ consisting mainly of post-war trial testimonies, which have obvious limitations. On occasion, distinct discrepancies between testimonies have led to contradictory interpretations, causing difficulties such as those faced in determining the locations of mass graves in the Rzuchów forest.

Meanwhile, a different perspective is provided by archaeological research, which in the early twenty-first century has consolidated its position in the context of crime scene research. ${ }^{3}$ The work carried out at former Nazi concentration and extermination camps has acquired a special character. Contemporary archaeology, including totalitarian archaeology, relies on written sources and iconography, as well as direct oral communication and eyewitness accounts. Archaeological excavations enable the acquisition of materials that could not be uncovered in any other way. Research methodologies, including the documentation of stratigraphic units, 
precise measurements and plans, the inventory of acquired materials, and comparative analysis, allow the broadening of the research perspective. Uncovered items cease to be purely evidential, taking on the status of monuments. Meanwhile, the context of their discovery at a memorial site gives them a new commemorative significance, and their exposition helps to reinstate the memory of the victims. ${ }^{4}$

\section{An outline of the camp's history}

The extermination camp in Chełmno nad Nerem (Kulmhof am Ner in German) was the first centre of this type organised by the Nazis, and the only one functioning in the area of the so-called Reichsgau Wartheland. ${ }^{5}$ The decision to create the camp was probably made as early as the summer of $1941^{6}$ and was influenced by the initiative undertaken at the level of local administrative structures, including by Arthur Greiser, an imperial lieutenant (Reichsstatthalter), who also served as the leader (Gauleiter) of the local division of the National Socialist German Workers' Party (NSDAP) (Nationalsozialistische Deutsche Arbeitspartei). ${ }^{7}$

The small village of Chełmno nad Nerem in the district of Kolski (Kr. Warthbrücken), located less than seventy kilometres from Łódź (Litzmannstadt), was chosen as the site for the camp. In November 1941 a special unit (Sonderkommando) arrived under the command of SS-Hauptsturmführer Herbert Lange. ${ }^{8}$ An estate located on the north-western edge of the town was annexed for the purpose of their operations. The old palace served as the main camp building, housing prisoners' cells and small workshops, as well as changing rooms for new arrivals. ${ }^{9}$ Later, victims would be taken through the basement corridor (sometimes referred to as the death corridor), at the end of which was a van that had been converted into a mobile gas chamber, located at the eastern entrance to the basement. The vehicle would then be driven to the Rzuchów forest, four kilometres outside the village, which was used as a cemetery.

The operation of the camp can be divided into two stages. The first lasted from 8 December 1941 (the first transport from nearby Koło) to 11 April 1943, when the commando unit left the area after blowing up most of the buildings, including the palace and the two crematoria that had been erected in the Rzuchów forest. In less than a year and a half, all provincial ghettos in the Reichsgau Wartheland (except the Łódź 'closed district'), which were concentrated mainly in the eastern part of Wielkopolska Province and around Łódź, were liquidated. ${ }^{10}$ During the first nine months of 1942 around 70,000 residents of the Łódź ghetto ${ }^{11}$ were subjected to mass deportations, including around 4,000 Roma and Sinti from the Łódź Gypsy camp (Zigeunerlager). ${ }^{12}$ Due to the worsening epidemiological situation, the transports were suspended for several weeks in the summer of 1942. Corpses were extracted from graves and burned, initially in open pits - SS-Standartenführer Paul Blobel was sent to Chełmno to take charge of 'Action 1005' (Aktion 1005, Sonderkommando 1005) $)^{13}$ - and later in specially constructed field crematoria. In March 1943 the decision was made to liquidate the camp.

The next German garrison arrived in March 1944 and started preparations to reopen the camp. As the palace had been destroyed, exterminations were carried 
out in the Rzuchów forest, where barracks were built to accommodate the victims. Between 23 June and 14 July 1944, ten transports arrived from the Łódź ghetto, carrying a total of 7,196 people. ${ }^{14}$ The action was discontinued after this date, most likely due to the rapidly changing situation on the Eastern Front and the approach of the Soviet army towards the Vistula. It was then decided that the Jews remaining in the ghetto would be deported to the Auschwitz-Birkenau concentration camp. ${ }^{15}$ Part of the German garrison and a group of the last Jewish prisoners remained in the village. They were tasked with destroying all traces of the camp's operation. The garrison evacuated the area on 18 January 1945; before they left, the last forty-five prisoners were executed by shooting or burned to death in the torched granary building.

Even today, it is difficult to determine the true number of victims killed at Chełmno. The lowest contemporary estimates indicate at least 152,000 victims, but most researchers have determined the figure to be between 170,000 and $200,000 .{ }^{16}$

\section{First excavations}

Despite the damage done by the German garrison, relics of several of the camp buildings were visible immediately after the liberation. The evidence was preserved in the memories of the local population. One local resident, Zofia Szałek, recalled at the time: 'we went to the granary straight away, we saw how those people had been burned' 17 They saw the remains of the palace and, most strikingly, the granary building that had been consumed by fire. Valuable information comes from the account of Józef Domżał, a resident of the nearby village:

I cross the gateway of the fenced-off area for the first time ... I visit all the other barracks. They're empty. There are four of them. One bigger than the others. The first housed the perpetrators' cars. In the second there was a reparations workshop. In the third, the small one, were the valuables of the murdered people. I don't know what the fourth one was for. The fifth was the old granary, converted into a concentration camp for handcuffed Jews ... ${ }^{18}$

Traces of the camp were also observed in the Rzuchów forest when a group of representatives of the Turek District Office arrived in April 1945. The head of the delegation, Jakub Waldman, a survivor of the ghetto in Czachulec (Heidemühle), noted: 'in one clearing were the remains of two graves, and in the other the remains of two destroyed stoves... as well as whole human bones... The other remains of the murders in the palace in Chełmno and in the Chełmski [Rzuchów - author's note] forests are a terrible, bloodcurdling sight. ${ }^{\text {'9 }}$ In May 1945 similar traces were documented by representatives of the Main Commission for the Investigation of German Crimes in Poland during their visit to the former camp area. As well as the mass graves, bone fragment, and the remains of the crematoria, they discovered several narrow-gauge railway tracks in the Rzuchów forest, which had been used as the grate in the crematorium furnace. ${ }^{20}$ 
All these findings influenced the decision to launch an investigation into the activities of the camp. In June 1945 this task was entrusted to Władysław Bednarz, a judge in the District Court in Łódź. ${ }^{21}$ He initiated enthusiastic operations, including excavations at the sites that were still clearly visible in the area. According to the laconically written documentation, the work was conducted on an ad hoc basis. The main aim was to reveal the mass graves, which would be treated as evidence in the investigation. As a result, the Jewish halachic tradition regarding the inviolability of the graves of the dead was ignored.

An attempt was made to dig up the so-called 'Włocławek grave', where six survey excavations were carried out. A statement from the District Commission for the Investigation of German Crimes in Łódź revealed that 'under the overgrown grass was a scorched layer of soil, below that there were human bones, and then, at a depth of about five metres below the surface, corpses in underwear, lying sometimes in one layer, sometimes two.'22 In November 1945 an unclassified 'glade planted with young birch ${ }^{23}$ was examined, and the pit used to burn corpses was discovered: 'at a depth of two metres, a forty to fifty centimetre thick layer of ash has been revealed in the sandy soil. The ash contains the remains of bones, hair, spoons, and charred metal tips from boots, as well as unburnt bones. ${ }^{24}$ Unfortunately, the lack of a plan or sketch of the area from that time makes it impossible to indicate precisely the sites of the two excavations.

The investigator demonstrated similar initiative on the premises of the former estate in Chełmno, where, in September 1945, in cooperation with officers of the Citizens' Militia and District Security Office, excavations were carried out near the granary. During the fifteen-day project one of the dumping pits was discovered between the building and the palace ruins. ${ }^{25}$ The entire undertaking was described only perfunctorily in the report: 'at a depth of about 1.5 metres, an intricate layer of various types of waste and burnt objects was found, including pans, pots, spoons, knives, forks, bags of food, etc. ${ }^{26}$ In the summary, the number of all excavated items was given as follows: ' 24,200 spoons . . , 4,500 pairs of scissors, around 250 forks, and a large number of knives, pliers, clippers, glasses, and all kinds of iron.27 The secured items were transported to the Magistrates' Court in Koło and then deposited at the safe of the District Court in Łódź. They disappeared in unexplained circumstances. ${ }^{28}$

At the same time the plundering of Jewish properties began. In the Rzuchów forest local residents were digging up mass graves and crematoria in search of 'yellow gold'. ${ }^{29}$ Similar incidents likely took place in the village itself, according to a letter addressed to the priest of the local parish, in which Bednarz wrote: 'I have been informed that a number of people have found parts of rosaries, medallions, crosses, etc., in the ruins of the former palace in Chełmno. Many of the parishioners do not want to disclose how they found these items or to submit them as material evidence. ${ }^{30}$ The ruins of the palace, where the building material was obtained, were also subjected to plundering. ${ }^{31}$ According to some authors, this practice remained on a small scale, ${ }^{32}$ although this view is difficult to verify, due to the lack of unambiguous sources. 


\section{Contemporary archaeological research}

In the second half of the 1980s, the voivodeship authorities decided to hand over the cemetery grounds to the District Museum in Konin. The museum director at the time, Łucja Pawlicka-Nowak, who was dedicated to saving Jewish heritage, was soon planning new excavations. This came as a direct result of the idea to establish a new museum facility, and the related need to acquire items for exhibition. ${ }^{33}$

An extensive interdisciplinary study was launched, including research based on archival sources, interviews with the local population and photographic interpretation of the terrain. These made it possible to carry out the first precise surveys within the cemetery in 1986-87, ${ }^{34}$ which involved an attempt to identify the topography and camp infrastructure. The fundamental problem faced by the researchers was the alteration in the structure of the terrain, resulting from clean-up work (including deep ploughing) and the construction of a memorial monument in the 1960s. Within the study area, located in the southern part of the largest camp clearing, five pits with a total area of $208 \mathrm{~m}^{2}$ were found. One contained the remains of a crematorium, including segments of reinforced concrete, bricks and large amounts of burned bones (excavation II). Two of the pits (IV and V) contained two shallow holes with fragments of burned bones, which were incorrectly assumed to have been pits for burning corpses. ${ }^{35}$ However, in areas where the remains of light wooden structures - such as the barracks used during the second phase of the camp - were anticipated to be found, no such traces were unearthed. On the other hand, a significant number of movable relics - items belonging to the victims - were obtained during the research.

Further research was suspended for financial reasons. It was not until state funds were acquired from the Council for the Protection of Struggle and Martyrdom Sites that the work could be resumed. In 1997 the research was once again focused on the area of the former estate in the village of Chełmno, where a substantial part of the former camp existed. The decision to conduct this research was dictated by the drastic transformations being made by the Commune Cooperative (which had been managing the area since the 1950s) and concerns about its further destruction. ${ }^{36}$

The research conducted in 1997 included the grounds of a nearby church, which had been directly connected to the camp as a storehouse for the possessions of murdered prisoners (1942) and a concentration building for deportees (1944). Three survey excavations were set up around the chancel. They revealed the traces of hearths used to destroy the victims' personal belongings, as evidenced by the numerous half-burned items discovered there. Research on the grounds of the estate itself focused on two main objectives: uncovering the remains of palace and exploring the dumping pits. The work was carried out over five years (1997-2001) around the central camp building and resulted in a full reconnaissance. In the first year the extent of the palace was established $(41.65 \times 13.68 \mathrm{~m})$; a corridor $(32.80 \times 1.20 \mathrm{~m})$ was revealed running through the cellars, along which victims were led to the gas chamber lorries; and several rooms were identified, including workshops and a prison cell. ${ }^{37}$ In 1998 the main entrance (used for formal occasions before the war) was unearthed, along with the staircase.$^{38}$ In 1999 the southern part of the building was 
investigated, revealing a series of further rooms, ${ }^{39}$ and the following year one of the two western entrances to the palace (which had been used to receive transports) was discovered. The comprehensive exploration of the ruins, in addition to the many items acquired, formed the basis for the interpretation of the functions of individual rooms:

in the basement located on the south side, counting from the west, there were three tailoring workshops and two shoemaking workshops. It is difficult to clearly determine whether there was an internal connection between them... Behind the five rooms determined as craft workshops, there were others, most likely sanitary facilities .... Behind those were another three rooms. ${ }^{40}$

In the final year the research focused on the area around the palace, revealing part of the transport route, among other things. ${ }^{41}$

In parallel, the research covered the remaining area of the land estate, where a number of survey excavations were set up, resulting in the discovery of nine dumping pits. ${ }^{42}$ The main part of the exploration work was carried out in 2002, revealing a range of victims' personal items. The conducted analysis made it possible to grasp the relationship between their chronology and the internal layout of the camp. 'Objects' associated with the first period (1941-43) were clustered in the area to the north and north-east of the granary. One of the pits was located between the granary and the palace. Meanwhile, the pits from the second period (1944) were located at the northern edge of the camp, in the garden area. ${ }^{43}$

In the period 2003-5 the research that had been interrupted sixteen years earlier in the Rzuchów forest was resumed. The main task facing the researchers was an attempt to determine the correct boundaries of the mass graves (which had been commemorated by the construction of the memorial monument in 1962-64) and the locations of the individual camp buildings. The specificity of the site, as well as halachic tradition, necessitated the adoption of a different research technique from that used by the investigators in 1945 . Thus, the survey excavations were set up in places where no mass graves were expected to be located, based on previous photographic interpretation. In the vicinity of the graves the turf and humus layers could be removed, but only to the point where stratigraphic disturbances were encountered. ${ }^{44}$ For verification purposes a hand-drilling method was used. ${ }^{45}$ This enabled the identification of 'objects' while keeping the structure of the graves intact. As a result, the perception of the internal topography of the cemetery changed completely. It was established that the actual scale of the graves was greater than had been previously assumed on the basis of witness accounts. In some cases it was possible to determine the creation date - the first grave was dated to January 1942. Particularly interesting results were obtained from the horizontal stratigraphy analysis of the largest mid-forest camp clearing, where it was possible to distinguish the so-called 'functional zones'. In the eastern part of the clearing two mass graves were discovered, along with a row of ten so-called 'field pits' that had served a sepulchral purpose. Meanwhile, in the western zone, a number of utility sites were found, including four crematoria - erected in the first and second periods ('object': $1 / 87$, 
$10 / 03,21 / 03,22 / 04$ ), four furnaces for burning corpses ('object': 2/03-4/03 and 20/03), and a yard for the bone grinder ('object': 23/04). ${ }^{46}$

The final round of research in the area of the former camp was conducted in the summer of 2016 as part of the preparatory works related to the construction of a new museum pavilion. Despite the small scope of the research, and its focus on the north-eastern section of the former estate in Chełmno, new, unexpected information was obtained. The findings of the research, conducted by the museum in cooperation with the University of Łódź Institute of Archaeology, included relics and impressions of stone and brick foundations that suggested the existence of two closely related buildings. The acquired movable materials, including numerous fragments of ceramic vessels, dated the sites from the early Middle Ages (thirteenth century) up to the seventeenth or eighteenth century. Historical surveys confirmed the researchers' hypotheses connecting the discovered buildings with the manor farm that still belongs to the archdiocese of Gniezno, which has managed the area of the village since the twelfth century. ${ }^{47}$

\section{Summary}

The archaeological work carried out over three decades has constituted one of the most important scientific and research-based undertakings relating to the former Kulmhof extermination centre in Chełmno nad Nerem. The fact that the work was conducted over a long period and covered such a wide area allowed for a comprehensive reconnaissance of the camp area, enabling the precise location of a number of 'objects'. Among other things, the structure of the former palace and the internal topography of the estate grounds were identified, and the role of the parish church in the extermination process was verified. In the Rzuchów forest the actual sizes and boundaries of the graves, and the locations of the crematoria and makeshift functional pits, were determined. Above all, a significant number of movable relics possessions of the victims - were acquired. These items constitute a testimony, serving as symbols of the crimes committed, and restoring the history and memory of the victims.

\section{Notes}

Translated from Polish by Cadenza Academic Translations.

1 See 'Obóz Zagłady Chełmno' ('Chełmno Extermination Camp’), Biuletyn Głównej Komisji Badania Zbrodni Niemieckich w Polsce (Bulletin of the Main Commission for the Investigation of German Crimes in Poland), 1 (1946), 147-64; W. Bednarz, Obóz straceń $w$ Chetmnie nad Nerem (The Execution Camp in Chetmno nad Nerem) (Warsaw, Państwowy Instytut Wydawniczy, 1946); E. Serwański, Obóz Zagłady w Chetmnie nad Nerem 1941-1945 (The Extermination Camp in Chetmno nad Nerem 1941-1945) (Poznań, Wydawn. Poznańskie, 1964); J. Gulczyński, Obóz śmierci w Chetmnie nad Nerem (The Death Camp in Chetmno nad Nerem) (Konin, Wojewódzki Ośrodek Kultury, 1991); Ł. Pawlicka-Nowak (ed.), Mówia świadkowie Chetmna (Chetmno's Witnesses Speak) (Konin, Rada Ochrony Pamięci Walki i 
Męczeństwa w Warszawie, Muzeum Okręgowe w Koninie; Łódź, Oficyna Bibliofilów Łódź, 2004); S. Krakowski, Das Todeslager Chełmno Kulmhof (Göttingen, Wallstein; Jerusalem, Yad Vashem, 2007); S. Krakowski, Chelmno: A Small Village in Europe. The First Nazi Mass Extermination Camp (Jerusalem, Yad Vashem, 2009); P. Montague, Chetmno and the Holocaust. The History of Hitler's First Death Camp (London and New York, 2012); P. Montague, Chetmno. Pierwszy nazistowski obóz zagłady (Chetmno. The First Nazi Extermination Camp) (Wołowiec, Czarne, 2014); Ł. Pawlicka-Nowak, Świadectwa Zagłady. Obóz w Chetmnie nad Nerem. Getto wiejskie Czachulec (Holocaust Testimonies. The Camp in Chetmno nad Nerem. The Czachulec Rural Ghetto) (Gdańsk, Muzeum II Wojny Światowej, 2014).

2 S. Abramowicz, 'Stan polskich badań nad ośrodkiem zagłady w Chełmnie nad Nerem' ('The State of Polish Research on the Extermination Centre in Chełmno nad Nerem'), in J. Kapustka, M. Loba and Z. Lorek (eds), Ośrodek zagłady w Chetmnie nad Nerem i jego rola $w$ hitlerowskiej polityce eksterminacyjnej (The Extermination Centre in Chetmno nad Nerem and its Role in the Nazi Extermination Policy) (Łódź-Konin, Muzeum Okregowe, 1995), p. 9.

3 I. Gilead, Y. Haimi and W. Mazurek, 'Excavating Nazi Extermination Centres', Present Pasts, 1 (2009), 10-39; C. Theune, 'Historical Archaeology in National Socialist Concentration Camps in Central Europe', Historische Archäologie, 2 (2010), 1-14; C. Sturdy Colls, 'Holocaust Archaeology: Archaeological Approaches to Landscapes of Nazi Genocide and Persecution', Journal of Conflict Archaeology, 7:2 (May 2012), 70-104; C. Theune, 'Archaeology and Remembrance: The Contemporary Archaeology of Concentration Camps, Prisoner-of-War Camps, and Battlefields', in N. Mehler (ed.), Historical Archaeology in Central Europe (Rockville, MD, Society for Historical Archaeology, 2013), 241-59; T. Lutz et al. (eds), Killing Sites - Research and Remembrance (Berlin, International Holocaust Remembrance Alliance, 2015); O. Ławrynowicz and J. Żelazko (eds), Archeologia totalitaryzmu. Ślady represji 1939-1956 (Totalitarian Archaeology. Traces of Repression 1939-1956) (Łódź, Instytut Pamięci Narodowej, 2015), pp. 9-19.

4 J. Pawlak, 'Miarą człowieczeństwa są rzeczy - dary dla Muzeum Historii Żydów Polskich w Warszawie' ('The Measure of Humanity is Things - Gifts for the Museum of the History of Polish Jews in Warsaw'), in Biografie rzeczy. Daryz kolekcji Muzeum Historii Żydów Polskich. Katalog wystawy (Gifts from the Collection of the Museum of the History of Polish Jews. Exhibition Catalogue) (Warsaw, 2013), pp. 12-18; A. Grzegorczyk, Rzeczy Zagłady (Things of the Holocaust) (Chełmno nad Nerem, 2014), p. 3.

5 C. Łuczak, Pod niemieckim jarzmem (Kraj Warty 1939-1945) (Under the German Yoke (Reichsgau Wartheland 1939-1945)) (Poznań, PSO, 1996), pp. 3-13.

6 J. Leszczyński, 'Od formuły obozu zagłady - Höppner-Chełmno n/Nerem - do "Endlösun"' ('From the Formula of the Höppner-Chełmno nad Nerem Extermination Camp to the "Endlösung”'), Biuletyn Żydowskiego Instytutu Historycznego (Bulletin of the Jewish Historical Institute), 101 (1977), 44-5.

7 J. A. Młynarczyk, 'Wpływ inicjatyw oddolnych Arthura Greisera i Odilona Globocnika na decyzję o wymordowaniu Żydów' ('The Impact of Arthur Greiser's 
and Odilo Globočnik's Grassroots Initiatives on the Decision to Murder Jews'), in A. Namysło (ed), Zagłada Żydów na polskich terenach wcielonych do Rzeszy (The Extermination of Jews on Polish Land Incorporated into the Reich) (Warsaw, Instytut Pamięci Narodowej. Komisja Ścigania Zbrodni przeciwko Narodowi Polskiemu, 2008), pp. 24-5.

8 From March 1942, SS-Hauptsturmführer Hans Bothmann took over the role of Sonderkommando leader at Kulmhof.

9 The granary and the church, located in the immediate vicinity of the main building, were also used for storage.

10 D. Dą browska, 'Zagłada skupisk żydowskich w "Kraju Warty” w okresie okupacji hitlerowskiej' ('The Extermination of Jewish Populations in the Reichsgau Wartheland during the Nazi Occupation'), Biuletyn Żydowskiego Instytutu Historycznego (Bulletin of the Jewish Historical Institute), 13-14 (1955), 122-84.

11 A. Löw, Getto łódzkie/Litzmannstadt Getto. Warunki życia i sposoby przetrwania (The Łódź Ghetto/Litzmannstadt Getto. Living Conditions and Survival Methods) (Łódź, Wydawnictwo Uniwersytetu Łódzkiego, 2012), pp. 209-43.

12 J. Barański, Zigeunerlager in Litzmannstadt 1941-1942 (The Gypsy Camp in Łódź 1941-1942) (Łódź, Archiwum Państwowe w Łodzi, Bilbo, 2003).

13 The results of his work were observed by Rudolf Höss, the Commandant of the Auschwitz-Birkenau concentration camp, during his visit to Chełmno in September 1942, who described a 'field furnace experimental station'; see Autobiografia Rudolfa Hössa. Komendanta obozu oświęcimskiego (The Autobiography of Rudolf Höss: Commandant of Auschwitz) (Warsaw, Wydawnictwo Prawnice, 1989), p. 191.

14 Löw, The Łódź Ghetto, pp. 349-50.

15 A. Strzelecki, Deportacje Żydów z getta łódzkiego do KL Auschwitz i ich zagłada. Opracowanie i wybór źródeł (The Deportation of Jews from the Łódź Ghetto to KL Auschwitz and their Extermination. Critical Analysis and Selection of Sources) (Oświęcim, 2004), pp. 32 et seq.

16 Montague, Chetmno and the Holocaust, pp. 292-8.

17 A. Skibińska, 'Wywiady z mieszkańcami Chełmna przeprowadzone przez the United States Holocaust Memorial Museum' ('Interviews with the Inhabitants of Chełmno Conducted by the United States Holocaust Memorial Museum'), in $€$. Pawlicka-Nowak (ed.), Ośrodek zagłady Żydów w Chełmnie nad Nerem w świetle najnowszych badań. Materialy z sesji naukowej (The Extermination Centre for Jews in Chetmno nad Nerem in Light of the Latest Research. Materials from the Scientific Session) (Konin, Muzeum Okręgowe, 2004), p. 51.

18 Archives of the Jewish Historical Institute (hereinafter, AJHI), ref. 302/220.

19 AJHI, ref. 301/5349.

20 Archiwum Akt Nowych (Archive of New Records), ref. 230/3, 'Sprawozdanie Komisji dla Badań Zbrodni Niemieckich w Polsce z pierwszego wyjazdu na teren obozu straceń w Chełmnie' ('Report of the Commission for the Investigation of German Crimes in Poland from the First Trip to the Execution Camp in Chełmno') (26 May 1945). 
21 Archives of the Institute of National Remembrance (hereinafter, AINR), Collection of objects, ref. 165/271, 'Akta śledztwa obozu straceń Chełmno' ('Records from the Investigation of the Chełmno Execution Camp'), vol. 1, p. 2.

22 AINR, District Commission for the Investigation of German Crimes in Łódź, ref. 165/19/1, 'Notatka z 25 VI 1945 r'. ('Note from 25 June 1945'), p. 104.

23 AINR, Collection of objects, ref. 165/271, vol. 6, p. 505.

24 Ibid., p. 505.

25 According to the documentation from research conducted in the period 1997-2005, this was assigned as pit number three. It was shaped like an irregular rectangle with the dimensions $4 \times 4.5 \mathrm{~m}$ at the top and $3.5 \times 4 \mathrm{~m}$ at the bottom, and a depth of $2 \mathrm{~m}$. Subsurface penetration from the 1945 research was also found, see Ł. Pawlicka-Nowak, 'Badania archeologiczne na terenie byłego ośrodka zagłady w Chełmnie nad Nerem' ('Archaeological Research in the Area of the Former Extermination Centre in Chełmno nad Nerem'), in Pawlicka-Nowak (ed.), Mówia świadkowie Chetmna, p. 53.

26 AINR, Collection of objects, ref. 165/271, vol. 4, p. 380.

27 Ibid., p. 380.

28 An enquiry conducted in recent years led to the discovery of only part of the documentation - for a list of 'objects' see $Ł$. Pawlicka-Nowak, Holocaust Testimonies, pp. 346-7.

29 Skibińska, 'Interviews with the Inhabitants of Chełmno', p. 54.

30 AINR, Collection of objects, ref. 165/271, vol. 3, p. 232.

31 Ł. Pawlicka-Nowak, J. Kapsutka and Z. Lorek, 'Prace archeologiczne na terenie pałacu w Chełmnie (w oparciu o dziennik badań)' ('Archaeological Work at the Palace in Chełmno (Based on the Research Log)'), Przeszłość i Pamięć. Biuletyn Rady Ochrony Pamięci Walk i Męczeństwa (Past and Memory. Bulletin of the Council for the Protection of Struggle and Martyrdom Sites), 3:4 (1997), 33.

32 Pawlicka-Nowak, Holocaust Testimonies, p. 313.

33 A. P. Zawadka, 'Historia i upamiętnienie byłego niemieckiego obozu zagłady w Chełmnie nad Nerem' ('History and Commemoration of the Former German Extermination Camp in Chełmno nad Nerem'), Past and Memory, 41 (2013), 142.

34 Informator Archeologiczny. Badania rok 1986 (Archaeological Guide: Research 1986) (Warsaw, Ministerstwo Kultury i Sztuki, Zarzad Museów i Ochrony Zabytków, 1987), p. 214; Informator Archeologiczny. Badania rok 1987 (Archaeological Guide: Research 1987) (Warsaw, Ministerstwo Kultury i Sztuki, Zarzad Museów i Ochrony Zabytków, 1988), p. 218.

35 Correct interpretation was only possible during the comprehensive research conducted in 2003 (when the site was assigned no. 2/03). This site was the second crematorium from the first period of the camp.

36 M. Grzanka and A. Grzegorczyk, 'Dzieje niepamięci. Powojenne losy byłego majątku w Chełmnie nad Nerem' ('History of Oblivion. The Post-War Fate of the Former Estate in Chełmno nad Nerem'), in M. Fabiszak, A. W. Brzezińska and M. Owsiński (eds), Znaki (nie)pamięci. Teoria i praktyka upamiętnienia w Polsce (Signs of Memory/ Oblivion. The Theory and Practice of Commemoration in Poland) (Kraków, Universita, 2016), pp. 181-9. 


\section{Andrzej Grzegorczyk}

37 Pawlicka-Nowak, Kapsutka and Lorek, 'Archaeological Work at the Palace in Chełmno', 34-6.

38 Ł. Pawlicka-Nowak and Z. Lorek, 'Badania archeologiczne w Chełmnie n. Nerem' ('Archaeological Research in Chełmno nad Nerem'), Past and Memory, 2:7 (1998), 49-50.

39 Ł. Pawlicka-Nowak, 'Badania archeologiczne na terenie ośrodka zagłady w Chełmnie nad Nerem' ('Archaeological Research at the Extermination Centre in Chełmno nad Nerem'), Past and Memory, 3:12 (1999), 70.

40 Ł. Pawlicka-Nowak, 'Badania archeologiczne w Chełmnie nad Nerem w 2000 r.' ('Archaeological Research in Chełmno nad Nerem in 2000'), Past and Memory, 3:16 (2000), 94.

41 Ł. Pawlicka-Nowak, 'Badania archeologiczne na terenie byłego ośrodka zagłady w Chełmnie n. Nerem w 2001 r.' ('Archaeological Research in the Area of the Former Extermination Centre in Chełmno nad Nerem in 2001'), Past and Memory, 1-2:22-3 (2002), 62-4.

42 Cf. Ł. Pawlicka-Nowak, 'Badania archeologiczne na terenie byłego niemieckiego ośrodka zagłady w Chełmnie nad Nerem' ('Archaeological Research in the Area of the Former German Extermination Centre in Chełmno nad Nerem'), in Ławrynowicz and Żelazko (eds), Totalitarian Archaeology, pp. 155-60, which gives the number of pits as eleven. However, this information is not reflected in the documentation or research reports.

43 Ł. Pawlicka-Nowak, 'Badania archeologiczne na terenie ośrodka zagłady w Chełmnie n. Nerem w 2002 r.' ('Archaeological Research in the Area of the Extermination Centre in Chełmno nad Nerem in 2002'), Past and Memory, 1-2:26-7 (2003), 74-8.

44 Ł. Pawlicka-Nowak, 'Wyniki badań archeologicznych przeprowadzonych w latach 2003-2004 na terenie cmentarzyska byłego ośrodka zagłady w Chełmnie n. Nerem (las rzuchowski)' ('The Results of Archaeological Research Carried Out in 2003-2004 at the Cemetery of the Former Extermination Centre in Chełmno nad Nerem (Rzuchów Forest)'), Past and Memory, 3-4:32-3 (2004), 84.

45 The effectiveness of this method was confirmed during work undertaken at other former extermination camps, such as Belzec; see A. Kola, Hitlerowski obóz zagłady Żydów w Bełżcu w świetle źródeł archeologicznych: badania 1997-1999 (The Nazi Extermination Camp for Jews in Belzec in the Light of Archaeological Sources: Research 1997-1999) (Warsaw; Washington, Rada Ochrony Pamięci Walk i Męczeństwa; USHMM, 2000), p. 11.

46 Pawlicka-Nowak, 'The Results of Archaeological Research Carried Out in 2003-2004', 88.

47 A. Andrzejewska and A. Grzegorczyk, 'Sprawozdanie z badań archeologicznych wyprzedzają cych budowę budynku wystawienniczo-administracyjnego na terenie Muzeum byłego niemieckiego Obozu Zagłady w Chełmnie nad Nerem' ('Report from the Archaeological Research Preceding the Construction of the Exhibition and Administrative Building at the Museum of the Former German Extermination Camp in Chełmno nad Nerem') (Chełmno-Łódź, 2016), unpublished material in the collection of the Martyrs' Museum in Żabikowo. 